INOBIS: Jurnal Inovasi Bisnis dan Manajemen Indonesia

Volume 1, Nomor 3, Juni 2018

Helwen Heri; Saut Maruba Sihombing

\title{
Analisis Pengaruh Dimensi Marketing Mix Terhadap Volume Penjualan Sepeda Motor Honda (Studi pada PT. Capella Dinamik Nusantara Riau)
}

\author{
Helwen Heri \\ Saut Maruba Sihombing \\ Universitas Lancang Kuning Pekanbaru
}

\begin{abstract}
Abstrak
PT. Capella Dinamik Nusantara adalah distributor resmi sepeda motor Honda di Provinsi Riau. Untuk mempertahankan pangsa pasar sepeda motor Honda, PT. Capella Dinamik Nusantara harus bisa mempertahankan atau bahkan meningkatkan penjualan secara lestari. Berbagai strategi dapat diberikan untuk meningkatkan volume penjualan, salah satunya adalah penerapan strategi dimensi Mix Marketing, dimana strategi ini terdiri dari produk, harga, distribusi dan promosi. Data penjualan sepeda motor Honda, terutama dalam 5 tahun terakhir (2011-2015), menunjukkan bahwa penjualan sepeda motor Honda berfluktuasi yang pada tahun 2012 mengalami penurunan sebesar 2,0\%, dan pada tahun 2013 turun sebesar 1,562\% namun pada tahun 2014 meningkat sebesar 4,084\% dan kemudian menurun. pada tahun 2015 sebesar $2.331 \%$. Kondisi di atas membutuhkan perhatian serius dari sisi manajemen PT. Capella Dinamik Nusantara dalam menerapkan strategi pemasaran untuk meningkatkan volume penjualan setiap tahunnya. Penelitian ini dilakukan untuk mengetahui signifikansi pengaruh dimensi Marketing Mix (produk, harga, distribusi dan promosi) untuk meningkatkan volume penjualan sepeda motor Honda di PT. Capella Dinamik Nusantara di Provinsi Riau dan Mengetahui variabel dominan dari Bauran Pemasaran (produk, harga, distribusi dan promosi) yang mempengaruhi kenaikan volume penjualan. Sampel penelitian terdiri dari konsumen yang membeli motor Honda pada tahun 2015. Data dikumpulkan dengan kuesioner dan dokumentasi, kemudian dianalisis secara kuantitatif. Hasil penelitian ini adalah sebagai berikut:
\end{abstract}

1. Produk dan Distribusi berpengaruh positif dan signifikan terhadap volume penjualan. Sedangkan Price memiliki pengaruh negatif dan signifikan terhadap volume penjualan. Dan dari pada Promotions memiliki pengaruh negatif dan tidak signifikan terhadap volume penjualan.

2. Produk, harga, distribusi (lokasi) dan promosi bersama-sama memiliki pengaruh positif dan signifikan terhadap volume penjualan. Hasil dari hipotesis ini akan lebih meyakinkan bahwa kolaborasi keempat variabel bauran pemasaran memiliki pengaruh positif dan signifikan terhadap volume penjualan. Hasilnya konsisten dengan penelitian yang dilakukan oleh Selma Indriyani (2002), Geraldy Tambajong (2013) dan Jamaladin Karim, dkk (2014) yang menunjukkan bahwa variabel bauran pemasaran terdiri dari produk, harga, distribusi (lokasi) dan promosi secara simultan berpengaruh terhadap volume penjualan

Kata Kunci: Bauran Pemasaran, Volume Penjualan 
INOBIS: Jurnal Inovasi Bisnis dan Manajemen Indonesia

Volume 1, Nomor 3, Juni 2018

Helwen Heri; Saut Maruba Sihombing

\section{Pendahuluan}

Dengan berkembangnya teknologi di era industri ini dapat dilihat berbagai produk yang dihasilkan. Kemudian dalam dunia usaha sekarang ini juga tingkat persaingan antara industriindustri bisnis semakin tajam, tak terkecuali dengan perusahaan-perusahaan yang berada di Indonesia. Dengan semakin majunya teknologi dalam era globalisasi ini, setiap perusahaan berusaha untuk selalu meningkatkan kualitas produksinya maupun manajemen pemasarannya dengan tujuan memaksimalkan keuntungan-keuntungan sesuai target yang diinginkan oleh setiap perusahaan. Persaingan yang semakin ketat dalam dunia bisnis telah merambah ke semua sektor usaha (bisnis), sehingga kompetisi yang ada antara perusahaan semakin ketat.

Meningkatnya jumlah sepeda motor di Indonesia dipengarui oleh beberapa faktor seperti jumlah penduduk. Jumlah penduduk yang terus bertambah akan menyebabkan kebutuhan juga bertambah sehingga permintaan terhadap barang dan jasa juga akan bertambah. Jumlah sepeda motor dalam suatu keluarga cenderung disesuaikan dengan kebutuhan anggota keluarga dalam penggunaannya, sehingga semakin banyak jumlah anggota keluarganya, maka memiliki kemungkinan untuk sepeda motor yang lebih juga. Hal ini dapat menunjukan bahwa jumlah penduduk memiliki pengaruh terhadap jumlah sepeda motor. Berikut adalah data tentang perbandingan peningkatan jumlah penduduk dengan jumlah sepeda motor di Indonesia dari tahun 2008-2012.

Tabel 1.1

\section{Pertumbuhan Jumlah Penduduk Indonesia Dengan Jumlah Sepeda Motor}

\begin{tabular}{|c|c|c|}
\hline Tahun & $\begin{array}{l}\text { Jumlah Penduduk } \\
\text { (dalam ribuan) }\end{array}$ & $\begin{array}{l}\text { Jumlah Sepeda Motor } \\
\text { (dalam ratusan) }\end{array}$ \\
\hline 2008 & 227.779 & 476.836 \\
\hline 2009 & 230.632 & 527.670 \\
\hline 2010 & 233.477 & 610.781 \\
\hline 2011 & 236.331 & 688.393 \\
\hline 2012 & 239.174 & 763.811 \\
\hline
\end{tabular}

Sumber : Statistik Indonesia dan Statistik Kependudukan

Berdasarkan tabel di atas dapat diketahui bahwa peningkatan jumlah penduduk dari tahun 2008 sampai dengan tahun 2012 diikuti dengan peningkatan jumlah sepeda motor yang ada. Peningkatan jumlah penggunaan sepeda motor juga dipicu oleh kondisi kemacetan di jalan raya yang menyebabkan aktifitas warga masyarakat menjadi lambat, sehingga banyak warga masyarakat memilih sepeda motor sebagai alat transportasi alternatif untuk mempercepat aktivitas mereka. Dengan menggunakan sepeda motor, perjalanan pun akan lebih mudah dan gampang lagi karena motor dapat menyalip ke kanan dan kiri mobil tanpa terhalang dengan kemacetan. Hal ini sesuai dengan yang dikatakan oleh Wakil Menteri Perhubungan Bambang Susantono dalam situs www.m.merdeka.com yaitu, transportasi publik belum termasuk dalam perancanaan tata ruang, sehingga sepeda motor dianggap sebagai alternatif untuk menurunkan kemacetan lalu lintas.

Harga murah dan mudah didapatkan juga dapat menyebabkan banyaknya jumlah pengguna sepeda motor, ditambah lagi dengan dealer dan institusi finansial memberikan 
INOBIS: Jurnal Inovasi Bisnis dan Manajemen Indonesia

Volume 1, Nomor 3, Juni 2018

Helwen Heri; Saut Maruba Sihombing

skema kredit yang terjangkau untuk memiliki sepeda motor sebagaimana yang telah diungkapkan oleh Wakil Menteri Perhubungan Bambang Susantono dalam situs www.m.merdeka.com.

Salah satu sepeda motor yang banyak digunakan oleh masyarakat sebagai alat transportasinya yaitu sepeda motor merek Honda. Berdasarkan informasi dari situs www.pekanbaru.tribunnews.com diketahui bahwa sepeda motor Honda semakin kukuh memegang tahta penguasa pasar sepeda motor nasional. Persentase penguasaannya bahkan semakin tinggi, mencapai 70,5 persen pada September 2015 dengan penjualan sebanyak 425.458 unit.

PT. Capella Dinamik Nusantara merupakan salah satu distributor resmi sepeda motor merek Honda yang ada di Provinsi Riau. Untuk tetap dapat mempertahankan penguasaaan pasar sepeda motor merek Honda, PT. Capella Dinamik Nusantara harus dapat mempertahankan atau bahkan meningkatkan penjualan secara berkelanjutan. Berbagai strategi dapat diakukan untuk meningkatkan volume penjualan, salah satunya adalah penerapan strategi Dimensi Marketing Mix (bauran pemasaran), dimana strategi ini terdiri atas produk, harga, distribusi dan promosi.

Dari sisi produk, PT. Capella Dinamik Nusantara menyediakan kebutuhan masyarakat dengan berbagai jenis tipe produk kendaraan roda dua merk Honda yang memiliki karakteristik yang berbeda-beda salah satunya yang dapat melewati jalanan macet dengan gesit seperti tipe matik dan memiliki kualitas model yang cocok untuk setiap kalangan, kualitas mesin yang awet serta cocok untuk digunakan oleh para remaja dan dewasa yang berjiwa muda. Sepeda motor Honda memiliki mesin yang berkualitas, hemat bahan bakar dan dapat digunakan untuk perjalanan dalam kota dan luar kota.

Untuk memudahkan pelanggan mendapatkan sepeda motor Honda yang mereka butuhkan, maka PT. Capella Dinamik Nusantara melakukan upaya distribusi dengan membuka kantor perwakilan berupa Sales Office atau Cabang penjualan di tingkat kecamatan pada setiap Kabupaten/Kota yang ada di Provinsi Riau. Jumlah sales office disesuaikan dengan populasi jumlah penduduk yang ada dalam satu kecamatan sehingga ada yang lebih dari satu cabang. Selanjutnya, penentuan kantor cabang atau sales office berada dilokasi keramaian yang mudah diakses dan dilihat oleh banyak orang. Upaya pemenuhan persedian sepeda motor untuk stok penjualan juga dilakukan agar pelanggan dapat membeli produk yang mereka inginkan. Adapun sales office penjualan yang dimiliki oleh PT. Capella Dinamik Nusantara di Provinsi Riau dapat dilihat seperti pada tabel 1.3.

Pengenalan produk agar diketahui dan diminati oleh masyarakat, maka perlu dilakukan upaya promosi. Promosi dapat dilakukan dengan berbagai media, mulai dari media massa, cetak, televisi, radio dan lain sebagainya. Dalam hal promosi, PT. Capella Dinamik Nusantara telah melakukan berbagai upaya dengan menggunakan media promosi yang ada, yaitu dengan membuat iklan promosi di surat kabar (riau pos, tribun, harian vokal dan lainnya), radio, televisi, brosur dan baliho-baliho. Selain melalui media yang telah disebutkan tadi, promosi juga dilakukan dengan pemasaran langsung kepada pelanggan dengan membuka stan di beberapa Mall yang ada, atau pada acara tertentu seperti pameran-pameran.

\section{Kerangka Berpikir Penelitian}

Berdasarkan tinjauan konsep dan penelitian terdahulu, maka dapat disusun suatu kerangka pemikiran dalam penelitian ini seperti yang disajikan dalam gambar 2.2. 
INOBIS: Jurnal Inovasi Bisnis dan Manajemen Indonesia

Volume 1, Nomor 3, Juni 2018

Helwen Heri; Saut Maruba Sihombing

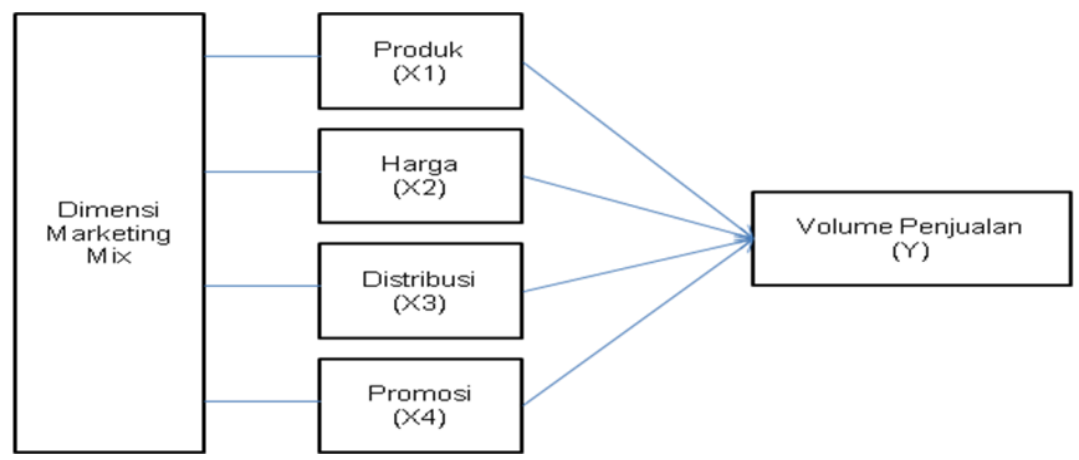

Gambar 2.2. Kerangka Berpikir Penelitian

Dari kerangka berpikir penelitian di atas menjelaskan bahwa variabel-variabel Dimensi Marketing Mix (Bauran Pemasaran) yang terdiri dari produk, harga, distribusi dan promosi secara parsial dan bersama-sama diperkirakan akan mempengaruhi tingkat volume penjualan sepeda motor Honda pada PT. Capella Dinamik Nusantara Riau,

\section{Hipotesis}

H1 : Semakin bagus produk yang ditawarkan semakin tinggi volume penjualan

$\mathrm{H} 2$ : Semakin terjangkau harga semakin tinggi volume penjualan

H3 : Semakin bagus akses distribusi semakin tinggi volume penjualan

$\mathrm{H} 4$ : Semakin bagus promosi semakin tinggi volume penjualan

H5 : Semakin bagus bauran pemasaran semakin tinggi volume penjualan

\subsection{Konsep dan Operasionalisasi Variabel Penelitian}

Menurut Sugiyono (2012:59), variabel merupakan suatu atribut atau sifat atau nilai dari orang, objek, atau kegiatan yang mempunyai variasi tertentu yang ditetapkan oleh peneliti untuk dipelajari dan ditarik kesimpulannya. Terdapat dua variabel di dalam penelitian ini, yaitu :

1. Variabel Bebas (independent)

Variabel bebas yaitu variabel yang menjadi sebab terjadinya atau terpengaruhnya variabel terikat. Variabel independent dalam penelitian ini adalah bauran pemasaran (dimensi marketing mix) yang didefinisikan menurut Kotler (Saputra, 2008:11), bauran pemasaran adalah seperangkat alat pemasaran yang digunakan perusahaan untuk terusmenerus mencapai tujuan pemasarannya di pasar sasaran. Elemen elemen bauran pemasaran (marketing mix) terdiri dari produk, harga, distribusi, dan promosi.

2. Variabel Terikat (dependent)

Variabel terikat adalah variabel yang nilainya dipengaruhi oleh variabel bebas. Tujuan dari metode dependent ini adalah untuk menentukan apakah variabel bebas mempengaruhi variabel terikat secara individual dan atau bersamaan. Dalam penelitian ini yang menjadi variabel terikat adalah keputusan pembelian. 
INOBIS: Jurnal Inovasi Bisnis dan Manajemen Indonesia

Volume 1, Nomor 3, Juni 2018

Helwen Heri; Saut Maruba Sihombing

Tabel 2.2

Operasionalisasi Variabel Penelitian

\begin{tabular}{|c|c|c|}
\hline Variabel & Defenisi Operasional & Indikator \\
\hline$x_{1}$ & $\begin{array}{l}\text { Product (produk) Segala sesuatu yang bisa } \\
\text { ditawarkan kepada sebuah pasar agar diperhatikan, } \\
\text { diminta, dipakai, atau dikonsums sehingga mungkin } \\
\text { memuaskan keinginan atau kebutuhan. (Kotler:2010) }\end{array}$ & $\begin{array}{l}\text { 1. Merek } \\
\text { 2. Model } \\
\text { 3. Kemasan } \\
\text { 4. Label } \\
\text { 5. Jaminan (garansi) } \\
\text { 6. Pelayanan } \\
\text { (Tjiptono:2008) }\end{array}$ \\
\hline$x 2$ & $\begin{array}{l}\text { Price (harga)- merupakan sejumlah uang yang } \\
\text { dibebankan atas suatu produk atau jasa atau jumlah } \\
\text { dari nilai yang ditukar konsumen atas manfaat- } \\
\text { manfaat karena memiliki atau menggunakan produk } \\
\text { atau jasa tersebut. (Kotler \& Amstrong:2006) }\end{array}$ & $\begin{array}{l}\text { 1. Keterjangkauan harga } \\
\text { 2. Kesesuaian harga dengan kualitas produk } \\
\text { 3. Daya saing harga } \\
\text { 4. Kesesuaian harga dengan manfaat } \\
\text { 5. Harga mempengaruhi daya beli konsumen } \\
\text { 6. Harga dapat mempengaruhikonsumen dalam } \\
\text { mengambil keputusan pembelian } \\
\text { (Kotler:2010) }\end{array}$ \\
\hline$x_{3}$ & $\begin{array}{l}\text { Places (tempatilokasi) - letak atau toko pengecer } \\
\text { pada daerah yang strategis sehingga dapat } \\
\text { memaksimumkan laba. (Swastha \& Irawan:2003) }\end{array}$ & $\begin{array}{l}\text { 1. Lokasi produk } \\
\text { 2. Ketersediaan produk } \\
\text { 3. Distribusi pesaing } \\
\text { 4. Daerah-daerah penjualan } \\
\text { Winardi dalam Karim: } 2014\end{array}$ \\
\hline$x 4$ & $\begin{array}{l}\text { Promotion (promosi) -merupakan aktivitas-aktivitas sebuah } \\
\text { perusahaan yang dirancang untuk memberikan informasi, membujuk } \\
\text { atau mengingatkan pihak-pihak lain tentang perusahaan yang } \\
\text { bersangkutan dan barangbarang serta jasa-jasa yang ditawarkan } \\
\text { olehnya. (Winardi dalam Saputra: 2008) }\end{array}$ & $\begin{array}{l}\text { 1. Tingkat kemenarikan iklan } \\
\text { 2. ingkat promosi penjualan } \\
\text { 3.. ublisitas pesaing. } \\
\text { 4. ublic relation } \\
\text { 5. emasaran langsung } \\
\text { (Tjiptono, Swasta, Winardi dalam Karim } \\
: 2014 \text { ) }\end{array}$ \\
\hline$\gamma$ & $\begin{array}{l}\text { Volume penjualan diartikan jumlah (kuantitas) produk hasil } \\
\text { produks perusahaan yang dikonsumsi oleh konsumen. (Abas } \\
\text { Kardaniata dalam R.M. Kumaat:2011) }\end{array}$ & $\begin{array}{l}\text { 1. Mencapai volume penjualan tertentu } \\
\text { 2. Mendapatkan laba tertentu } \\
\text { 3. Menunjang pertumbuhan perusahaan. } \\
\text { (Kotler dalam Swasta \& Irawan : 2003) }\end{array}$ \\
\hline
\end{tabular}

\section{Metode Penelitian}

\subsection{Populasi dan Sampel Penelitian}

Menurut Sugiyono (2012:80) populasi adalah wilayah generalisasi yang terdiri atas : Obyek/subyek yang mempunyai kualitas dan karakteristik tertentu yang ditetapkan oleh peneliti untuk dipelajari dan kemudian ditarik kesimpulannya. Populasi yang digunakan dalam penelitian ini adalah konsumen yang melakukan peningkatan penjualan sepeda motor Honda pada PT. Capella Dinamik Nusantara di Propinsi Riau.

Sampel adalah bagian dari jumlah dan karakteristik yang dimiliki oleh populasi tersebut (Sugiyono, 2012:81). Pada penelitian ini populasi penelitian adalah jumlah konsumen yang melakukan pembelian sepeda motor Honda atau jumlah penjualan PT. Capella Dinamik Nusantara tahun 2015 dan terdiri atas beberapa wilayah (cluster) yaitu sebanyak 11 (sebelas) wilayah Kabupaten/Kota di Provinsi Riau, karena 11 (sebelas) wilayah ini terdapat perwakilan penjualan PT. Capella Dinamik Nusantara.

Penentuan sampel dalam penelitian ini dilakukan dengan tahapan sebagai berikut :

1. Jumlah populasi ditentukan sebanyak jumlah penjualan PT. Capella Dinamik Nusantara total di 11 (sebelas) wilayah Kabuapten/Kota Provinsi Riau tahun 2015 yaitu sebanyak 126.946 orang konsumen. 
INOBIS: Jurnal Inovasi Bisnis dan Manajemen Indonesia

Volume 1, Nomor 3, Juni 2018

\section{Helwen Heri; Saut Maruba Sihombing}

2. Penentuan sampel tahap pertama digunakan teknik Cluster Sampling (Area Sampling) yaitu menentukan wilayah yang akan diambil sampelnya dari 11 (sebelas) wilayah yang ada mengingat luasnya area sumber data, keterbatasan waktu dan biaya. Adapun wilayah yang akan diambil sampelnya adalah sebanyak 5 (lima) wilayah dengan alasan wilayah tersebut memiliki jarak yang relatif dekat dengan tempat peneliti tinggal yaitu Kota Pekanbaru (33.921), Kabupaten Kampar (15.566), Kabupaten Pelalawan (5.499), Kabupaten Siak (9.802) dan Kabupaten Bengkalis (13.339) dengan total jumlah sebanyak 78.127 orang konsumen.

3. Penentuan jumlah sampel tahap kedua sebagai sumber data selanjutnya menggunakan rumus Slovin (Riduwan, 2012:65), sebagai berikut :

$$
\begin{aligned}
\boldsymbol{n} & =\text { Error! Reference source not found. } \\
& =\text { Error! Reference source not found. } \\
=99,9 & =\text { dibulatkan menjadi } 100 \text { sampel }
\end{aligned}
$$

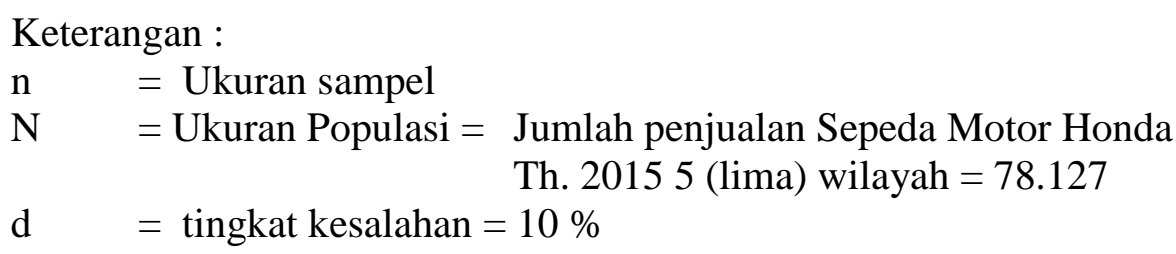

4. Penentuan jumlah sampel tahap ketiga untuk setiap wilayah menggunakan rumus proporsi sebagai berikut:Error! Reference source not found. (Sugiyono 2013.138) Keterangan :

$\mathrm{s}=$ Jumlah sampel setiap unit secara proporsional

$\mathrm{S}=$ Jumlah seluruh sampel yang didapat

$\mathrm{N}=$ Jumlah Populasi

$\mathrm{n}=$ Jumlah masing-masing unit populasi

Berdasarkan rumus diatas maka diperoleh jumlah sampel per wilayah pada tabel 3.1 berikut :

Tabel 3.1

Jumlah sampel per wilayah

\begin{tabular}{|c|l|c|c|}
\hline No & Kabupaten & $\begin{array}{c}\text { Unit } \\
\text { Populasi }\end{array}$ & Sampel \\
\hline 1 & Pekanbaru & 33.921 & 43 \\
\hline 2 & Kampar & 15.566 & 20 \\
\hline 3 & Bengkalis & 13.339 & 17 \\
\hline 4 & Siak & 9.802 & 13 \\
\hline 5 & Pelalawan & 5.499 & 7 \\
\hline \multicolumn{2}{|c|}{ Total Populasi } & $\mathbf{7 8 . 1 2 7}$ & $\mathbf{1 0 0}$ \\
\hline
\end{tabular}

Adapun pertimbangan individu yang dijadikan sampel adalah pemilik dan pengguna sepeda motor Honda yang berdomisili di wilayah (cluster) yang telah ditetapkan sebagai area sampling dalam penelitian ini. 
INOBIS: Jurnal Inovasi Bisnis dan Manajemen Indonesia

Volume 1, Nomor 3, Juni 2018

Helwen Heri; Saut Maruba Sihombing

\section{Hasil dan Pembahasan}

\subsection{Pengujian Persyaratan Analisis}

Penggunaan Statistik Parametris mensyaratkan bahwa setiap variabel yang akan dianalisis harus berdistribusi normal. Oleh karena itu sebelum pengujian hipotesis dilakukan, maka terlebih dulu akan dilakukan pengujian normalitas data.

Dalam multiple regresi yang baik seharusnya tidak terjadi korelasi antara variabel bebas. Jika variabel bebas saling berkorelasi maka variabel-variabel ini tidak orthogonal. Variabel orthogonal adalah variabel bebas yang nilai korelasi antar sesamanya sama dengan nol, maka dari itu perlu dilakukan pengujian multikolenieritas.

Dalam model regresi seharusnya juga tidak terjadi ketidaksamaan variance dari residual satu pengamatan ke pengamatan lain atau disebut dengan heteroskedastisitas. Untuk melihat apakah model regresi terdapat heteroskedastisitas maka perlu dilakukan pengujian heteroskedastisitas.

Adapun hasil pengujian persyaratan analisis di atas adalah sebagai berikut :

\subsection{Uji Multikolenieritas}

Pengujian multikolenieritas juga dilakukan dengan bantuan aplikasi SPSS V. 19, dimana analisis multikolenieritas dilihat dari nilai tolerance dan Variance Inflation Factor (VIF). Nilai Cut-off yang sering dipakai untuk menjelaskan adanya multikolenieritas adalah nilai tolerance $<0,10$ atau sama dengan nilai VIF $>10$. (Ghozali, 2011:96). Dilihat dari hasil pengujian maka dapat dikatakan bahwa seluruh data penelitian tidak terdapat multikoleniertitas. Rincian hasil perhitungan uji multikolenieritas adalah seperti pada tabel berikut :

Tabel 4.12

Perhitungan Multikolenieritas

\begin{tabular}{|l|l|l|l|l|l|}
\hline Variabel & Sig & Std & VIF & Std & Keterangan \\
\hline Produk & 0,950 & 0,1 & 1,052 & 10 & $\begin{array}{l}\text { Tidak Terdapat } \\
\text { Multikolenieritas }\end{array}$ \\
\hline Harga & 0,206 & 0,1 & 4,849 & 10 & $\begin{array}{l}\text { Tidak Terdapat } \\
\text { Multikolenieritas }\end{array}$ \\
\hline Lokasi & 0,210 & 0,1 & 4,771 & 10 & $\begin{array}{l}\text { Tidak Terdapat } \\
\text { Multikolenieritas }\end{array}$ \\
\hline Promosi & 0,996 & 0,1 & 1,004 & 10 & $\begin{array}{l}\text { Tidak Terdapat } \\
\text { Multikolenieritas }\end{array}$ \\
\hline
\end{tabular}

Dari tabel 4.12 diketahui bahwa hasil pengujian multikolenieritas dengan melihat nilai tolerance dan Variance Inflation Factor (VIF), seluruh nilai signifikan variabel penelitian di atas standar 0,1 dan nilai VIF di bawah standar 10, dengan demikian data penelitian disimpulkan tidak terjadi multikolenieritas.

\subsection{Uji Heteroskedastisitas}


INOBIS: Jurnal Inovasi Bisnis dan Manajemen Indonesia

Volume 1, Nomor 3, Juni 2018

\section{Helwen Heri; Saut Maruba Sihombing}

Pengujian heteroskedastisitas tetap dilakukan dengan bantuan aplikasi SPSS V. 19, untuk menguji apakah dalam model regresi terjadi ketidaksamaan variance dengan residual antara pengamatan satu dengan pengamatan yang lain.

Tabel 4.13

\section{Perhitungan Heteroskedastisitas}

Coefficients $^{a}$

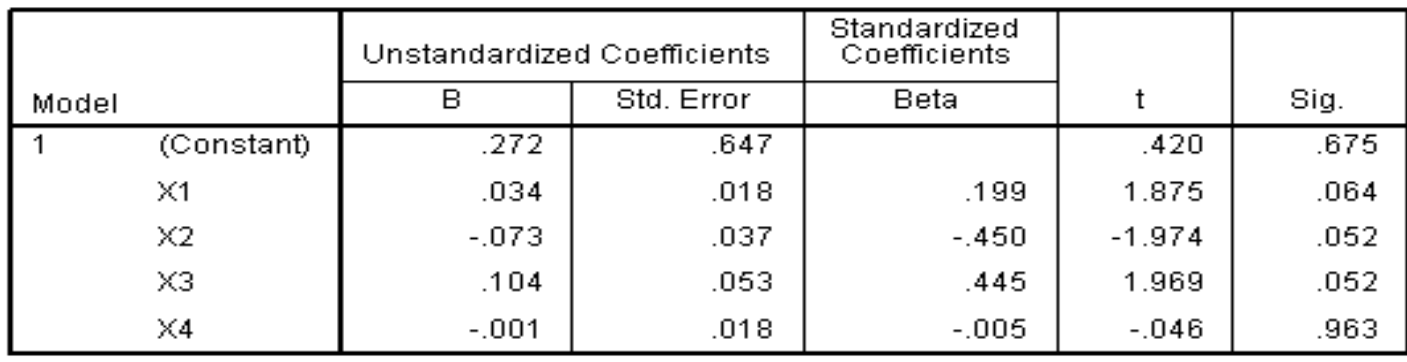

a. Dependent Variable: ABS_Res5

Dari tabel 4.13 diketahui bahwa P Value sebesar 0.675 dan lebih besar dari 0.05 dengan demikian tidak terjadi heteroskedastisitas.

\subsection{Analisis Regresi Linear Berganda}

Adapun hasil analisis regresi linear berganda dalam penelitian ini adalah sebagai berikut

Tabel 4.14

Hasil Analisis Regresi Linear Berganda

Coefficients $^{\mathrm{a}}$

\begin{tabular}{|c|c|c|c|c|c|c|c|c|c|c|c|}
\hline \multirow[b]{2}{*}{ Mode } & & \multicolumn{2}{|c|}{ Unstandardized Coefficients } & \multirow{2}{*}{$\begin{array}{c}\begin{array}{c}\text { Standardized } \\
\text { Coefficients }\end{array} \\
\text { Beta }\end{array}$} & \multirow[b]{2}{*}{$t$} & \multirow[b]{2}{*}{ Sig. } & \multicolumn{3}{|c|}{ Correlations } & \multicolumn{2}{|c|}{ Collinearity Statistics } \\
\hline & & B & Std. Error & & & & Zero-order & Partial & Part & Tolerance & VIF \\
\hline \multirow[t]{5}{*}{1} & (Constant) & 8.668 & 1.259 & & 6.885 & .000 & & & & & \\
\hline & $\mathrm{X} 1$ & .191 & .035 & .509 & 5.391 & .000 & .459 & .500 & .496 & .950 & 1.052 \\
\hline & $X_{2}$ & -.178 & .072 & -.502 & -2.479 & .015 & -.035 & -.257 & -.228 & .206 & 4.849 \\
\hline & $\mathrm{X} 3$ & .230 & .103 & .449 & 2.235 & .028 & .025 & .233 & .206 & .210 & 4.771 \\
\hline & $\mathrm{X} 4$ & .003 & .035 & .007 & .072 & .943 & .021 & .008 & .007 & .996 & 1.004 \\
\hline
\end{tabular}

a. Dependent Variable: $Y$

Persamaan regresi tersebut mempunyai makna sebagai berikut:

a. $\quad$ Konstanta $\mathbf{= 8 , 6 6 8}$

Jika variabel produk, harga, lokasi dan promosi dianggap sama dengan nol, maka variabel volume penjualan sebesar $\mathbf{8 , 6 6 8}$.

b. $\quad$ Koefisien Harga $\left(\mathrm{X}_{1}\right)=\mathbf{0 , 1 9 1}$

Jika variabel produk mengalami kenaikan, sementara harga, lokasi dan promosi diasumsikan tetap, maka volume penjualan akan meningkat sebesar $\mathbf{0 , 1 9 1}$.

c. $\quad$ Koefisien Produk $\left(\mathrm{X}_{2}\right)=\mathbf{- 0 , 1 7 8}$

Jika variabel harga mengalami penurunan, sementara produk, lokasi dan promosi diasumsikan tetap, maka volume penjualan akan menurun sebesar $\mathbf{0 , 1 7 8}$.

d. $\quad$ Koefisien Lokasi $\left(\mathrm{X}_{3}\right)=\mathbf{0 , 2 3 0}$ 
INOBIS: Jurnal Inovasi Bisnis dan Manajemen Indonesia

Volume 1, Nomor 3, Juni 2018

Helwen Heri; Saut Maruba Sihombing

Jika variabel lokasi mengalami kenaikan, sementara produk, harga dan promosi diasumsikan tetap, maka volume penjualan akan meningkat sebesar 0,230.

e. $\quad$ Koefisien Promosi $\left(\mathrm{X}_{4}\right)=\mathbf{- 0 , 0 3}$

Jika variabel promosi mengalami penurunan, sementara produk, harga dan lokasi diasumsikan tetap, maka volume penjualan akan menurun sebesar $\mathbf{0 , 0 3 1}$.

\subsection{Pengujian Hipotesis}

Pengujian Hipotesis dilakukan untuk menguji hipotesis yang telah dirumuskan apakah hipotesis tersebut dapat diterima atau ditolak. Pengujian hipotesis dalam penelitian ini dilakukan secara parsial untuk membuktikan pengaruh signifikan dari masing-masing variabel bebas (independen) terhadap variabel terikat (dependen) penelitian dan secara serentak untuk membuktikan pengaruh signifikan dari seluruh variabel bebas (independen) secara bersamasama terhadap variabel terikat (independen) penelitian. Adapun hasil pengujian hipotesis dalam penelitian ini adalah sebagai berikut :

\subsection{Pengujian Hipotesis Secara Parsial (Uji t)}

Adapun hasil analisis dengan Uji t dalam penelitian ini adalah sebagai berikut :

Tabel 4.15

Hasil Uji t

\begin{tabular}{|c|c|c|c|c|c|c|}
\hline \multirow{2}{*}{\multicolumn{2}{|c|}{ Model }} & \multicolumn{2}{|c|}{ Unstandardized Coefficients } & \multirow{2}{*}{$\begin{array}{c}\begin{array}{c}\text { Standardized } \\
\text { Coefficients }\end{array} \\
\text { Beta }\end{array}$} & \multirow[b]{2}{*}{$\mathrm{t}$} & \multirow[b]{2}{*}{ Sig. } \\
\hline & & B & Std. Error & & & \\
\hline \multirow[t]{5}{*}{1} & (Constant) & 8.668 & 1.259 & & 6.885 & .000 \\
\hline & $\mathrm{X} 1$ & 191 & .035 & .509 & 5.391 & .000 \\
\hline & $\times 2$ & -.178 & .072 & -.502 & -2.479 & .015 \\
\hline & X3 & .230 & .103 & .449 & 2.235 & .028 \\
\hline & $\times 4$ & .003 & .035 & .007 & .072 & .943 \\
\hline
\end{tabular}

a. Dependent Variable: $Y$

Berdasarkan tabel 4.15 dapat dijelaskan berdasarkan hipotesis yang telah dirumuskan sebagai berikut :

1) Variabel produk $\left(\mathrm{X}_{1}\right)$ berpengaruh signifikan terhadap volume penjualan sepeda motor Honda pada PT. Capella Dinamik Nusantara Riau

Diketahui hasil analisis dari tabel 4.15 bahwa nilai thitung variabel Produk (X1) adalah sebesar 5,391 > $\mathrm{t}_{\text {tabel }}$ sebesar 1,985, maka $\mathrm{H}_{\mathrm{a}}$ yang menyatakan bahwa variabel produk berpengaruh secara signifikan terhadap volume penjualan sepeda motor Honda pada PT. Capella Dinamik Nusantara Riau dapat diterima.

2) Variabel harga berpengaruh signifikan terhadap volume penjualan sepeda moto Honda pada PT. Capella Dinamik Nusantara Riau. Dari hasil analisis tabel 4.15 di atas diketahui bahwa nilai thitung variabel Harga (X2) adalah sebesar $-2,479<t_{\text {tabel }}$ sebesar $-1,985$, maka $\mathrm{H}_{\mathrm{a}}$ yang menyatakan bahwa variabel harga berpengaruh secara signifikan terhadap volume penjualan sepeda motor Honda pada PT. Capella Dinamik Nusantara Riau dapat diterima. 
INOBIS: Jurnal Inovasi Bisnis dan Manajemen Indonesia

Volume 1, Nomor 3, Juni 2018

Helwen Heri; Saut Maruba Sihombing

3) Variabel distribusi berpengaruh signifikan terhadap volume penjualan sepeda motor Honda pada PT. Capella Dinamik Nusantara Riau. Berdasarkan hasil analisis dari tabel 4.15 di atas terlihat bahwa nilai thitung variabel distribusi (lokasi) adalah sebesar 2,235 > $\mathrm{t}_{\text {tabel }}$ sebesar 1,985, maka $\mathrm{H}_{\mathrm{a}}$ yang menyatakan bahwa variabel distribusi (lokasi) berpengaruh secara signifikan terhadap volume penjualan sepeda motor Honda pada PT. Capella Dinamik Nusantara Riau dapat diterima.

4) Variabel promosi berpengaruh signifikan terhadap volume penjualan sepeda motor Honda pada PT. Capella Dinamik Nusantara Riau. Masih dari hasil analisis tabel 4.15 juga diketahui bahwa nilai thitung variabel Promosi (X4) adalah sebesar 0,072 > $t_{\text {tabel }}$ sebesar 1,985, maka $\mathrm{H}_{\mathrm{a}}$ yang menyatakan bahwa variabel promosi berpengaruh secara signifikan terhadap volume penjualan sepeda motor Honda pada PT. Capella Dinamik Nusantara Riau ditolak. Dari hasil uraian di atas dapat dikatakan bahwa 3 (tiga) variabel yaitu variabel produk, harga dan distribusi (lokasi) berpengaruh secara signifikan terhadap volume penjualan sehingga hipotesis penelitian dapat diterima, sementara 1 (satu) variabel yaitu variabel promosi ternyata tidak berpengaruh secara signifikan terhadap volume penjualan sehingga hipotesis penelitian ditolak.

Berdasarkan tabel 4.15 juga diketahui bahwa dari ketiga variabel bebas (independen) produk, harga dan distribusi (lokasi) yang berpengaruh secara signifikan terhadap variabel terikat (dependen) volume penjualan maka variabel produk merupakan variabel bebas (independen) yang berpengaruh signifikan secara dominan terhadap variabel terikat (dependen) volume penjualan karena memiliki sig. $0,000<0,05$, diikuti dengan variabel bebas (independen) harga dan distribusi (lokasi) dengan nilai sig. 0,015 $<0,05$ dan sig. 0,028 $<0,05$.

\subsection{Pengujian Hipotesis Secara Serempak (Uji F)}

Uji F dilakukan untuk melihat keberartian pengaruh variabel bebas (independen) secara serentak terhadap variabel terikat (dependen) atau sering disebut uji kelinieran persamaan regresi. Analisis dilakukan dengan alikasi SPSS V. 19, dimana keputusan diterima atau ditolaknya hipotesis ditentukan dengan membandingkan nilai $\mathrm{F}$ hitung dengan $\mathrm{F}$ tabel dengan ketentuan :

Jika $\mathrm{F}_{\text {hitung }}>\mathrm{F}_{\text {tabel, }}$ maka $\mathrm{H}_{0}$ ditolak, $\mathrm{H}_{\mathrm{a}}$ diterima ; dan

Jika $\mathrm{F}_{\text {hitung }}<\mathrm{F}_{\text {tabel, }}$, maka $\mathrm{H}_{0}$ diterima, $\mathrm{H}_{\mathrm{a}}$ ditolak.

Nilai $\mathrm{F}$ tabel ditentukan dengan ketentuan taraf signifikan $=0,05$, maka nilai $\mathrm{F}$ tabel $=$ 2,467. Sugiyono (2012:192)

Hasil uji F dapat dilihat pada tabel 4.16

Tabel 4.16

Hasil Uji F 
INOBIS: Jurnal Inovasi Bisnis dan Manajemen Indonesia

Volume 1, Nomor 3, Juni 2018

Helwen Heri; Saut Maruba Sihombing

\begin{tabular}{|ll|r|r|r|r|r|}
\hline Model & & \multicolumn{1}{|c|}{$\begin{array}{c}\text { Sum of } \\
\text { Squares }\end{array}$} & df & Mean Square & F & Sig. \\
\hline 1 & Regression & 44.207 & 4 & 11.052 & 7.753 & $.000^{a}$ \\
& Residual & 124.011 & 87 & 1.425 & & \\
& Total & 168.217 & 91 & & & \\
\hline
\end{tabular}

a. Predictors: (Constant), $\times 4, \times 2, \times 1, \times 3$

b. Dependent Variable: $Y$

Berdasarkan tabel 4.16 diketahui bahwa nilai $\mathrm{F}_{\text {hitung }}(7,753)>\mathrm{F}_{\text {tabel }}(2,467)$, ini berarti variabel bebas (independen) produk, harga, distribusi (lokasi) dan promosi secara serentak benar-benar berpengaruh signifikan terhadap variabel terikat (dependen) volume penjualan. Maka dengan kata lain variabel-variabel bebas (independen) produk, harga, distribusi (lokasi) dan promosi mampu menjelaskan besarnya variabel terikat (dependen) volume penjualan. Dengan demikian hipotesis yang menyatakan terdapat pengaruh yang signifikan dari variabel bauran pemasaran yang terdiri atas produk, harga, distribusi, dan promosi terhadap volume penjualan sepeda motor Honda pada PT. Capella Dinamik Nusantara Riau dapat diterima.

\subsection{Koefisien Determinasi}

Untuk melihat besarnya pengaruh variabel bebas (independen) terhadap variabel terikat (dependen) dapat dilihat dari koefisien determinasi-nya. Adapun besarnya koefisien determinasi pada penelitian ini adalah sebagai berikut :

\subsection{Hasil Koefisien Determinasi $\left(\mathbf{R}^{2}\right)$}

\begin{tabular}{|l|l|r|r|r|r|}
\hline Model & $\mathrm{R}$ & $\mathrm{R}$ Square & $\begin{array}{c}\text { Adjusted R } \\
\text { Square }\end{array}$ & $\begin{array}{c}\text { Std. Error of } \\
\text { the Estimate }\end{array}$ & $\begin{array}{r}\text { Durbin- } \\
\text { Watson }\end{array}$ \\
\hline 1 & $.513^{\mathrm{a}}$ & .263 & .229 & 1.19390 & 1.833 \\
\hline
\end{tabular}

a. Predictors: (Constant), $\times 4, \times 2, \times 1, \times 3$

b. Dependent Variable: $Y$

Pada tabel diatas diperoleh nilai Adjusted $\mathrm{R}^{2}=0,229=22,9 \%$ (Sugiyono, 2012:185). ini berarti variabel bebas (independen) produk, harga, distribusi (lokasi) dan promosi secara bersama-sama mempengaruhi variabel terikat (dependen) volume penjualan sebesar $22,9 \%$ dan sisanya dipengaruhi oleh variabel lain yang tidak masuk dalam penelitian ini.

\subsection{Pembahasan}

Hasil penelitian menunjukkan bahwa secara simultan variabel produk, harga, distribusi (lokasi) dan promosi berpengaruh signifikan terhadap volume penjualan sepeda motor merek Honda pada PT. Capella Dinamik Nusantara Wilayah Riau. Hasil ini sesuai dengan pendapat Kotler (dalam R.M.Kumaat, 2011: 28), bahwa indikator dari volume penjualan antara lain : Harga, Promosi, Kualitas, Saluran Distribusi, Produk. Berdasarkan indikator tersebut maka strategi bauran pemasaran diperlukan dalam meningkatkan volume penjualan.

Besarnya pengaruh keempat variabel tersebut terhadap volume penjualan tidaklah terlalu besar yaitu sebesar 22,9\% namun berpengaruh secara signifikan. Dengan demikian, walaupun pengaruh keempat variabel independen tersebut terhadap volume penjualan tidak terlalu besar harus menjadi perhatian bagi pihak manajemen PT. Capella Dinamik Nusantara wilayah Riau dalam penjualan produk sepeda motor merek Honda. 
INOBIS: Jurnal Inovasi Bisnis dan Manajemen Indonesia

Volume 1, Nomor 3, Juni 2018

Helwen Heri; Saut Maruba Sihombing

\subsection{Pengaruh Produk terhadap Volume Penjualan Sepeda Motor Merek Honda Pada PT. Capella Dinaik Nusantara}

Hasil penelitian ini menunjukkan adanya pengaruh produk secara parsial positif dan signifikan terhadap volume penjualan sepeda motor merek Honda pada PT. Capella Dinamik Nusantara wilayah Riau. Produk yang ditawarkan kepada masyarakat sangatlah beragam dan dirancang sesuai dengan kebutuhan dalam berbagai jenis tipe produk kendaraan roda dua merk Honda yang memiliki karakteristik yang berbeda-beda salah satunya yang dapat melewati jalanan macet dengan gesit seperti tipe matik dan memiliki kualitas model yang cocok untuk setiap kalangan, kualitas mesin yang awet serta cocok untuk digunakan oleh para remaja dan dewasa yang berjiwa muda. Sepeda motor Honda memiliki mesin yang berkualitas, hemat bahan bakar dan dapat digunakan untuk perjalanan dalam kota dan luar kota.

\subsection{Pengaruh Harga terhadap Volume Penjualan Sepeda Motor Merek Honda Pada PT. Capella Dinamik Nusantara}

Hasil penelitian ini menunjukkan adanya pengaruh harga secara parsial negatif dan signifikan terhadap volume penjualan sepeda motor merek Honda pada PT. Capella Dinamik Nusantara wilayah Riau. Geraldy Tambajong (2013) menyatakan bahwa harga berpengaruh secara signifikan terhadap volume penjualan. Harga memiliki pengaruh yang besar terhadap konsumen untuk membeli. Setiap konsumen membutuhkan lebih banyak bentuk diskon atau potongan harga dan paket barang dengan harga yang murah. Faktor harga produk selalu menjadi faktor penting dalam proses dalam konteks setiap pembelian pelanggan/konsumen. Berdasarkan hasil uji $\mathrm{t}$ diperoleh keterangan bahwa variabel harga berpengaruh negatif terhadap volume penjualan secara signifikan. Ini berarti semakin naik harga yang ditawarkan berakibat pada semakin turun volume penjualan. Besarnya pengaruh variabel harga terhadap keputusan pembelian adalah 12,25\%.

Harga yang ditetapkan PT. Capella Dinamik Nusantara mengacu pada keterjangkauan harga, dan kesesuaian dengan kualitas produk. Selain itu juga dilakukan discount atau potongan harga yang diberikan guna mendorong konsumen agar membeli dalam jumlah yang lebih banyak, sehingga meningkatkan volume penjualan secara keseluruhan.

\subsection{Pengaruh Distribusi (Lokasi) terhadap Volume Penjualan Sepeda Motor Merek Honda Pada PT. Capella Dinaik Nusantara}

Hasil penelitian ini menunjukkan adanya pengaruh distribusi (lokasi) produk secara parsial positif dan signifikan terhadap volume penjualan sepeda motor merek Honda pada PT. Capella Dinamik Nusantara wilayah Riau. Distribusi (lokasi) meliputi aktifitas perusahaan yang membuat produk tersedia pada pelanggan sasaran. Besarnya pengaruh variabel distribusi (lokasi) terhadap volume penjualan adalah 5,42\%.

\subsection{Pengaruh Promosi terhadap Volume Penjualan Sepeda Motor Merek Honda Pada PT. Capella Dinaik Nusantara}


INOBIS: Jurnal Inovasi Bisnis dan Manajemen Indonesia

Volume 1, Nomor 3, Juni 2018

Helwen Heri; Saut Maruba Sihombing

Hasil penelitian ini menunjukkan bahwa terdapat pengaruh negatif yang tidak signifikan variabel promosi terhadap volume penjualan sepeda motor merek Honda pada PT. Capella Dinamik Nusantara wilayah Riau. Promosi dipandang sebagai arus informasi atau persuasif satu arah yang dibuat untuk mempengaruhi seseorang atau organisasi kepada tindakan yang menciptakan pengukuran dalam pemasaran. Besarnya pengaruh variabel promosi terhadap volume penjualan adalah $4,41 \%$.

Hasil pengujian secara parsial menunjukkan bahwa sumbangan efektif dari masingmasing variabel bebas terhadap penelitian, ternyata variabel produk mempunyai pengaruh yang paling dominan terhadap volume penjualan, sedangkan variabel promosi mempunyai pengaruh yang tidak signifikan terhadap volume penjualan.

\subsection{Pengaruh Dimensi Bauran Pemasaran terhadap Volume Penjualan Sepeda Motor Merek Honda Pada PT. Capella Dinamik Nusantara}

Hasil penelitian ini menunjukkan bahwa terdapat pengaruh yang signifikan antara variabel dimensi bauran pemasaran (Marketing Mix) yaitu produk, harga, distribusi (lokasi) dan promosi terhadap volume penjualan sepeda motor merek Honda pada PT. Capella Dinamik Nusantara wilayah Riau. Dimensi bauran pemasaran (Marketing mix) merupakan seperangkat alat pemasaran taktis dan terkontrol yang dipadukan oleh perusahaan untuk menghasilkan respon yang diinginkan pasar sasaran. Bauran pemasaran terdiri atas segala sesuatu yang dapat dilakukan perusahaan untuk mempengaruhi permintaan produknya. Besarnya pengaruh variabel dimensi bauran pemasaran (Marketing Mix) terhadap volume penjualan adalah sebesar $22,9 \%$.

\section{Kesimpulan}

Berdasarkan hasil penelitian yang dilakukan oleh penulis maka kesimpulan dari penelitian ini adalah sebagai berikut :

1. Produk mempunyai pengaruh positif dan signifikan terhadap volume penjualan. Pada pengujian ini telah dibuktikan bahwa hipotesis dapat diterima. Kesimpulan yang diterima dari hipotesis ini adalah elemen-elemen yang terdapat dalam atribut suatu produk akan mempengaruhi peningkatan volume penjualan. Elemen-elemen seperti kualitas produk yang baik, merek dagang yang terkenal merupakan beberapa elemen yang dapat meningkatkan volume penjualan. Adanya hubungan positif yang signifikan dan dominan yang dimiliki oleh elemen ini menunjukkan bahwa variabel ini sangat vital untuk diperhatikan.

2. Harga mempunyai pengaruh negatif dan signifikan terhadap volume penjualan. Pada pengujian ini telah dibuktikan bahwa hipotesis dapat diterima. Salah satu indikator dari variabel harga adalah keterjangkauan harga. Semakin terjangkau harga yang ditawarkan akan semakin meningkatkan kemampuan pembelian konsumen yang berdampak pada peningkatan volume penjualan.

3. Distribusi (Lokasi) memiliki pengaruh positif dan signifikan terhadap volume penjualan. Pada pengujian ini telah dibuktikan bahwa hipotesis dapat diterima. Distribusi berhubungan langsung dengan proses perpindahan produk dari produsen ke konsumen melalui saluran pemasaran. Semakin baik manajemen distribusi (lokasi) suatu produk akan meningkatkan image konsumen yang diharapkan mampu meningkatkan volume penjualan. 
INOBIS: Jurnal Inovasi Bisnis dan Manajemen Indonesia

Volume 1, Nomor 3, Juni 2018

Helwen Heri; Saut Maruba Sihombing

4. Promosi memiliki pengaruh negatif dan tidak signifikan terhadap volume penjualan. Pada pengujian ini telah dibuktikan bahwa hipotesis ditolak. Hubungan negatif yang dimiliki oleh variabel promosi terhadap volume penjualan dalam penelitian ini tidak dapat membuktikan pandangan bahwa promosi merupakan aktivitas-aktivitas sebuah perusahaan yang dirancang untuk memberikan informasi, membujuk atau mengingatkan pihak-pihak lain tentang perusahaan yang bersangkutan dan barang-barang serta jasa-jasa yang ditawarkan olehnya.

5. Produk, harga, distribusi (lokasi) dan promosi secara bersama-sama mempunyai pengaruh yang positif dan signifikan terhadap volume penjualan. Pada pengujian ini telah dibuktikan bahwa hipotesis dapat diterima. Hasil uji hipotesis ini akan semakin meyakinkan bahwa kolaborasi keempat variabel bauran pemasaran (Marketing Mix) memiliki pengaruh positif dan signifikan terhadap volume penjualan. Hasil penelitian ini sejalan dengan penelitian yang dilakukan oleh Selma Indriyani (2002), Geraldy Tambajong (2013) dan Djamaluddin Karim, dkk (2014) yang menunjukkan bahwa secara simultan variabel bauran pemasaran yang terdiri atas produk, harga, distribusi (lokasi) dan promosi berpengaruh secara signifikan terhadap volume penjualan.

\section{Saran}

Berdasarkan hasil analisis data dan pembahasan serta simpulan di atas, adapun saran yang diberikan adalah :

1. Dalam penetapan harga harus berhati-hati. Karena dengan adanya kenaikan harga yang tinggi, kemungkinan akan mengakibatkan tingkat volume penjualan menurun. Selain itu, perusahaan harus secara rutin melakukan analisa persaingan untuk produk sepeda motor yang sejenis.

2. Pada variabel distribusi (lokasi) pengaruhnya rendah dibandingkan variabel lainnya. Dalam hal ini pihak manajemen perusahaan harus lebih baik melakukan usaha kajian atau studi strategis terhadap kebijakan distribusi (lokasi) yang dibuat dengan mempertimbangkan segenap aspek yang menentukan tepat atau tidaknya kebijakan distribusi (lokasi) yang dibuat. Sehingga kebijakan distribusi (lokasi) yang dibuat dapat meningkatkan volume penjualan

\section{Daftar Pustaka}

Alma, Buchari. 2008. Manajemen Pemasaran dan Pemasaran Jasa, Alfabeta, Bandung

Arikunto, Suharsimi, 2010, Prosedur Penelitian Suatu Pendekatan Praktik. Rineka Cipta, Jakarta

Djaslim Saladin, 2007, Manajemen Pemasaran, Linda Karya, Bandung

Geraldy Tambajong, 2013, Bauran Pemasaran Pengaruhnya Terhadap Penjualan Sepeda Motor Yamaha Di PT. Sarana Niaga Megah Kerta Manado, Jurnal EMBA Vol. 1 No. 3 September 2013, Hal. 1291-1301

Ghozali, Imam, 2011, Aplikasi Analisis Multivariate Dengan Program IBM SPSS 19 (edisi kelima), Universitas Diponegoro, Semarang

Hair, et al., 2010, Multivariate Data Analysis, Seventh Edition, Pearson Prentice Hall, New Jersey

Hermann, et, al. 2007, "The social influence of brand community: evidence from European car clubs", Journal of Marketing, Vol. 69, p 19 - 34. 
INOBIS: Jurnal Inovasi Bisnis dan Manajemen Indonesia

Volume 1, Nomor 3, Juni 2018

Helwen Heri; Saut Maruba Sihombing

Indriyani, Selma, 2002, Analisis Pengaruh Bauran Pemasaran Produk Plastik Terhadap Volume Penjualan (Studi Kasus PT. Mitraya Plasindo Sejati Surabaya), Tesis Program Studi Magister Manajemen Universitas Diponegoro Semarang

Karim, Djamaluddin, dkk, 2014, Marketing Mix Pengaruhnya Terhadap Volume Penjualan Pada PT. Manado Sejati Perkasa Group, Jurnal EMBA Vol. 2 No. 1 Maret 2014

Kotler, Philip dan Keller, Kevin Lane. 2009. Manajemen Pemasaran Jilid 1, Edisi kedua belas, Alih Bahasa oleh Benyamin Molan. Jakarta: PT. Indeks

Kotler, Philip dan Amstrong. 2006. Manajemen Pemasaran Jilid 1 Edisi kedua belas. Jakarta: PT. Indeks

Kotler, Philip, 2010, Manajemen Pemasaran, Erlangga,Jakarta

Kumaat, R.M., dkk., 2011, Pengaruh Bauran Pemasaran terhadap Volume Penjualan Minyak Goreng Kemasaran Bermerk di Kota Manado, http://www.unsrat.ac.id

Kuntjojo, 2009, Metodologi Penelitian, Diktat Perkuliahan, Kediri

Kuswarak, 2010, Analisis Bauran Pemasaran Terhadap Volume Penjualan Nata De Coco Ukuran 220 GR Pada PT. Keong Nusantara Abadi Natar Lampung Selatan, Fakultas Ekonomi Universitas Sang Bumi Ruwa Jurai, Jurnal Sains dan Inovasi 6 (1) 35-38 (2010)

Ningrum, Windi Sulistiya, 2012, Pengaruh Saluran Distribusi dan Harga Jual Terhadap Volume Penjualan Sandal Pada UKM Sandal di Mojokerto, Universitas Negeri Surabaya, Jurnal Volume 01 Nomor 01 Tahun 2012, 0-126

Rajput, A.A.; Kalhoro, S.H.; dan Wasif, R. 2012. Impact of Product Price and Quality on Consumer Buying Behavior: Evidence from Pakistan. Interdisciplinary Journal Of Contemporary Research In Business. ijcrb.webs.com. Vol 4, No 4. August, h.585-496.

Riduwan, 2012, Dasar-Dasar Statistika, Alfabeta, Bandung

Saputra, Hendra. 2008. Analisis Pengaruh Strategi Bauran Pemasaran Terhadap Keputusan Pembelian Teh Celup Sariwangi oleh Konsumen Rumah Tangga di Kota Medan. Medan: Sekolah Pascasarjana Universitas Sumatera Utara.

Siregar, Syofian, 2013, Metode Penelitian Kuantitatif, Kecana, Jakarta

Sugiyono, 2012, Metode Penelitian Kuantitatif Kualitatif Dan $R \& D$, Alfabeta, Bandung

Suliyanto, 2013, Metode Riset Bisnis, Penerbit Andi, Yogyakarta

Swastha, Basu DH dan Irawan. 2003. Manajemen Pemasaran Modern. Liberty, Yogyakarta.

Swastha, Basu, 2007, Azas Azas Marketing, Penerbit Liberty Yogyakarta.

Tjiptono, Fandy, 2008, Strategi Pemasaran. Edisi ke dua, penerbit Andi Offset, Yogyakarta. 